\title{
Coronavirus outbreaks including COVID-19 and impacts on medical education: A systematic review
}

\author{
Kelly, ${ }^{*}$ Lie Rebecca Yen Hwei, Gilbert Sterling Octavius
}

Faculty of Medicine, University of Pelita Harapan, Karawaci, Tangerang, Banten, Indonesia

SUBMITTED: 20 June 2020

REVISED: 19 July 2020

ACCEPTED: 19 July 2020

KEYWORDS

COVID-19

Medical education

MERS

SARS

\begin{abstract}
Since the beginning of 2020 , the world has been affected by the novel coronavirus COVID-19 pandemic. The virus' infectious nature pushed all sectors to implement social distancing measures in an effort to limit its transmission, including the education sector. We searched PubMed and Science Direct on June 12th and found 24 papers that are relevant to our review. After the World Health Organization announced that COVID-19 is a global threat, various countries took a variety of measures to limit the disease spread such as social distancing, selfquarantine, and closing public facilities that hold large gathering, including universities and schools. Hospitals started to prioritize services for COVID-19 cases. Medical education programs are also affected by this disease, but not continuing in-person classes outweighs any benefit from traditional teaching methods. The previous Severe Acute Respiratory Syndrome (SARS) and Middle East Respiratory Syndrome (MERS) pandemics have shown ways to shift medical education to online platforms. In the current pandemic, online meetings are being used to hold lectures, classes, laboratory practices, and clinical skills classes. For clerkship students, online platforms might not be feasible because this eliminates patient-doctor relationships, but it appears for now to be the only option. Some institutions have involved medical students in the frontlines altogether. We encourage all parties to constantly evaluate, review, and improve the efforts of continuing medical education, especially during this pandemic. Further research is needed to evaluate students' performance after adopting e-learning and to discover the best methods in medical education in general and clerkship education in particular.
\end{abstract}

(C) The Journal 2020. This article is distributed under a Creative Commons Attribution-ShareAlike 4.0 International license.

\section{Introduction}

At the beginning of December 2019, there was the first unknown case of pneumonia with unknown origin in Wuhan, the capital city of Hubei. ${ }^{1}$ The pathogen was identified as a novel enveloped RNA beta coronavirus that has been named Severe Acute Respiratory Syndrome Coronavirus 2 (SARS-CoV-2) which has a phylogenetic similarity to SARS-CoV.,3 The World Health Organization (WHO) declared SARS-CoV- 2 as a pandemic on the $30^{\text {th }}$ of January 2020 and naming it officially COVID-19 on the $11^{\text {th }}$ of February $2020 . .^{4}$ Indonesia reported its first and second cases on March $2^{\text {nd }}, 2020.4,5$ As of June $3^{\text {rd }}$, 2020, the Government of Indonesia had announced

*Correspondence: tjhai.kelly@hotmail.com

Faculty of Medicine, Pelita Harapan University, Jl. Jend. Sudirman No.20, Bencongan, Kec. Klp. Dua, Tangerang, Banten 15810, Indonesia
28,233 confirmed cases of COVID-19, 1,698 deaths and 8,406 recovered cases from 418 districts across all 34 provinces. ${ }^{6}$

This pandemic has affected Indonesia in almost all sectors ranging from financial and investment business to aviation, tourism, hotels, restaurants, shipping, and education sectors. ${ }^{7,8}$ Indonesia's Ministry of Education decided that all physical learning activities would be done from home on March $9^{\text {th }}, 2020$ in order to break the chain of transmission. ${ }^{9}$

School closure was meant to reduce the transmission and the number of cases by promoting physical distancing. However, this was based on influenza pandemic settings and it was unclear whether the school measures are effective in coronavirus outbreaks such as Severe Acute Respiratory Syndrome (SARS), Middle East 
Respiratory Syndrome (MERS), and most specifically, COVID-19 for which the transmission dynamics appear to be different. ${ }^{10} \mathrm{~A}$ systematic review in 2014 done by the UK Department of Health found that during the influenza pandemic, school closures resulted in greater reductions in the peak number of cases more than in cumulative attack rates and according to modelling studies, are likely to have the greatest effect if the virus has low transmissibility with a reproductive number less than $2 .{ }^{11}$

Learning from home or e-learning means that all teaching and learning activities will be done electronically with the help of the internet. This means that professors and lecturers will have to adapt and change their way of teaching to suit the environment of e-learning while students will have a new role to become proactive, independent learners, and problem solvers. ${ }^{12}$ This includes the medical students, both pre-clerkship and clerkship students.

In this unprecedented time, almost all sectors are uncertain on how to act including the medical education field. We are now in a dire need more than ever to prepare future physicians as this global pandemic hits and yet practical, ethical, and logistical challenges exist as medical students may potentially spread or acquire the virus during training, thereby endangering both themselves, their family, or other patients. ${ }^{13}$

In most parts of the world, medical students are advised to stay at home and do their part by physical distancing while some countries have recruited their final-year students for hospital-based roles so that they can serve as frontline clinicians. ${ }^{14-16}$ In America, the American Association of Medical Colleges (AAMC) has instructed medical schools to suspend student clerkships and recommended that medical students should not be involved directly in in-patient care activities unless there is a critical health care workforce needed. ${ }^{17}$

For some pre-clerkship students, adjusting to e-learning might seem rushed but not out of place. Their learning routines can be replaced with the advantages of digital technology since lectures can be delivered via online platforms, small-group discussions are convened easily, and materials uploaded and downloaded at ease.${ }^{13}$ However, these adjustments might fall short on general examinations if they are conducted online as well, which means that there is no way to check and ensure whether integrity was upheld. ${ }^{18}$ There are also increased challenges in terms of the use of email, sense of isolation, and struggles with establishing boundaries between work and home which may have an adverse effect on students' and staffs' wellbeing. ${ }^{13}$

The bigger issue exists within the clerkship learning environment. During the clerkship phase, medical students are required to learn directly from their patients with supervision. Learning in this method marks a shift from the learning in the lecture halls and textbooks to hospital settings and real-world patients with whom medical students will work one day in the future. This means that the clinical portion of medical education will remain focused on hospitals, physician offices, patients' homes, and other settings while the most pivotal aspect of teaching in these settings occurs in the apprenticeship model. ${ }^{19}$ This model cannot be replaced by learning from home which would revert the apprenticeship model back to the pre-clerkship way of teaching and learning.

Many universities and teaching hospitals are uncertain on how to best provide medical education during these tough times, including in Indonesia. However, this was not the first coronavirus outbreak that has happened since there was SARS in $2003^{20,21}$ and MERS in 2012 22,23 which also affected the way medical students learn. Since there is little information on how to best deal with the COVID-19 pandemic in terms of teaching and learning for medical students, both those in pre-clerkship and clerkship, we did a systematic review to answer the following questions: "What are the effects of learning from home for both undergraduate medical students and clerkship students during COVID-19" and "What can we learn from previous coronavirus outbreaks in terms of medical education?"

\section{Method}

The authors (K, LR, GS) searched PubMed with database-appropriate syntax: "'Middle East Respiratory Syndrome Coronavirus" $[\mathrm{mh}]$ OR "Middle East Respiratory Syndrome*"[tw] OR 
"MERS-CoV"[tw] OR MERS [tw] OR "Middle Eastern Respiratory Syndrome*"[tw] OR "MERSCoV*" [tw] OR SARS [tw] OR "Severe Acute Respiratory Syndrome" $[\mathrm{mh}]$ OR "Severe Acute Respiratory Syndrome" OR coronavirus[mh] OR Coronavirus Infections[mh] OR coronavirus*[tw] OR "COVID19" $[\mathrm{tw}]$ or "2019-nCoV"[tw] or "SARS-CoV-2"[tw]) AND (Medical Education[mh:noexp]). The search was conducted on the $12^{\text {th }}$ of June 2020 and the review was done in accordance with Preferred Reporting Items for Systematic Review and Meta-Analyses (PRISMA) guidelines. ${ }^{24}$

Because there is a lack of class I or grade A evidence on this topic, we did not exclude any study designs nor papers such as letters to editors, editorials, perspectives and reviews. Article selections were limited to those available in English as fullpaper only. Further selection was determined via our Population, Intervention, Comparison, and Outcome (PICO) in which population included undergraduate medical students and clerkships only. All other stages of medical education including residence and fellows as well as other fields of medical specialties such as veterinary were excluded. Interventions included any impacts and innovations towards medical education during this pandemic. Comparison was done with what has been done during MERS and SARS outbreaks while Outcome was defined as the outcome that entails the interventions towards medical students and co-assistants.

After screening for duplicates in the two databases and removing them, all three authors ( $\mathrm{K}$, $L R$, and GS) independently scanned titles and/or abstracts while applying the PICO as the selection criteria. All three authors had to agree to include each particular paper in order for that article's full paper to be screened. When there was consensus, those articles together with the selected abstracts or articles would be chosen for full-text screening. Again, individual assessment was done by each author and any conflicts were resolved internally by strictly referring back to our assessment criteria. The included articles were then processed for qualitative analysis.

\section{Result}

We found 2,127 papers on COVID-19 and medical education (799 from PubMed and 1,328 from Science Direct), 2,755 papers on MERS and medical education (409 from PubMed and 2346 from Science Direct),

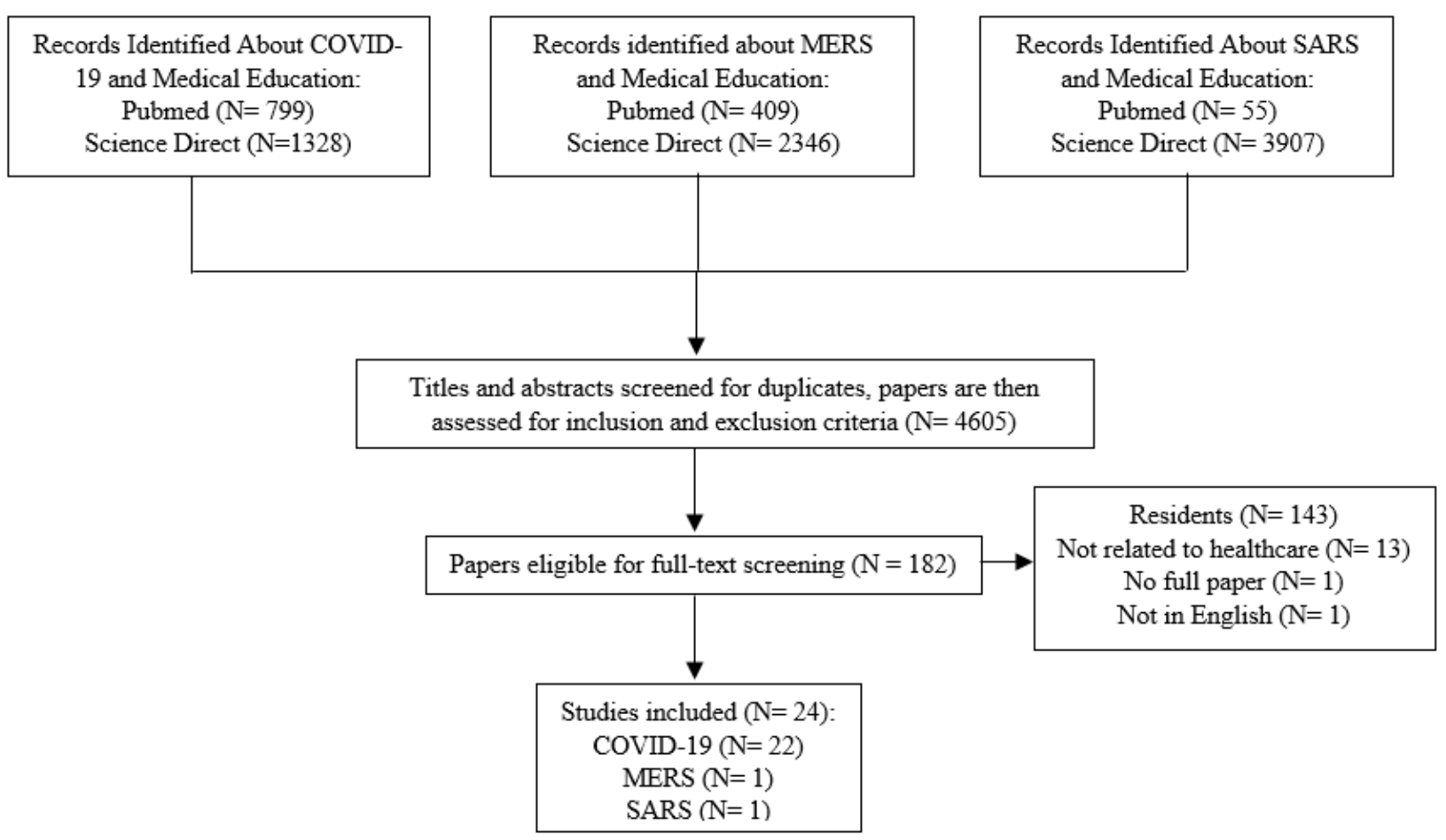

Figure 1. Flow-diagram of search strategy 
Table 1. Characteristics of studies included

\begin{tabular}{|c|c|c|c|c|}
\hline Authors & Study type & $\begin{array}{l}\text { Pandemic } \\
\text { situation }\end{array}$ & Target population & Results/Conclusions \\
\hline Sahi et $\mathrm{al}^{25}$ & Commentary & COVID-19 & $\begin{array}{l}\text { Medical students and } \\
\text { clerkship students }\end{array}$ & $\begin{array}{l}\text { Medical education cannot halt every time there is a } \\
\text { threat (pandemic). }\end{array}$ \\
\hline Ashokka et $\mathrm{al}^{26}$ & Commentary & COVID-19 & $\begin{array}{l}\text { Medical students and } \\
\text { clerkship students }\end{array}$ & $\begin{array}{l}\text { A paradigm shift (e-learning) might already be } \\
\text { happening. }\end{array}$ \\
\hline Singh et $\mathrm{a}^{27}$ & Cross-sectional & COVID-19 & Medical students only & $51 \%$ prefer physical classes over e-classes. \\
\hline $\begin{array}{l}\text { Kanneganti } \\
\text { et } \mathrm{al}^{28}\end{array}$ & Editorial & COVID-19 & $\begin{array}{l}\text { Clerkship students } \\
\text { only }\end{array}$ & $\begin{array}{l}\text { Virtual Continuing Medical Education (vCME) is an } \\
\text { important strategy in the prolonged campaign against } \\
\text { COVID-19. }\end{array}$ \\
\hline $\begin{array}{l}\text { Almarzooq et } \\
\text { al }^{29}\end{array}$ & Editorial & COVID-19 & $\begin{array}{l}\text { Clerkship students } \\
\text { only }\end{array}$ & $\begin{array}{l}\text { Program-specific virtual learning platforms have the } \\
\text { potential to play an important and useful role. }\end{array}$ \\
\hline Akers et $\mathrm{a}^{30}$ & Commentary & COVID-19 & $\begin{array}{l}\text { Clerkship students } \\
\text { only }\end{array}$ & $\begin{array}{l}\text { The current situation necessitates an adaptation for all } \\
\text { involved academically. }\end{array}$ \\
\hline Calhoun et $\mathrm{al}^{31}$ & Editorial & COVID-19 & $\begin{array}{l}\text { Clerkship students } \\
\text { only }\end{array}$ & Rotations are cut short and adjusted accordingly. \\
\hline Sahu $\mathrm{P}^{32}$ & Commentary & COVID-19 & Medical students only & $\begin{array}{l}\text { Faculty members should embrace technology and pay } \\
\text { careful attention to students' learning experiences. }\end{array}$ \\
\hline Lapolla et al ${ }^{33}$ & Editorial & COVID-19 & $\begin{array}{l}\text { Medical students and } \\
\text { clerkship students }\end{array}$ & $\begin{array}{l}\text { Medical board exams were changed and resulted in } \\
\text { fast-tracking of doctors. }\end{array}$ \\
\hline Tabari et al ${ }^{34}$ & Letter to Editor & COVID-19 & Medical students only & $\begin{array}{l}\text { Three cycle model might help restructuring medical } \\
\text { education curriculum. }\end{array}$ \\
\hline Franchi $\mathrm{T}^{35}$ & Letter to Editor & COVID-19 & Medical students only & $\begin{array}{l}\text { There is a more fundamental emotional experience that } \\
\text { cannot be achieved by learning anatomy via online. }\end{array}$ \\
\hline $\begin{array}{l}\text { Longhurst et } \\
\mathrm{al}^{36}\end{array}$ & $\begin{array}{l}\text { Descriptive } \\
\text { Article }\end{array}$ & COVID-19 & Medical students only & $\begin{array}{l}\text { It is hoped that adaptations will lead to lasting positive } \\
\text { changes. }\end{array}$ \\
\hline $\begin{array}{l}\text { Gonzalez- } \\
\text { Zamora et al }{ }^{37}\end{array}$ & Editorial & COVID-19 & Medical students only & $\begin{array}{l}\text { Further studies are required to assess acceptance, } \\
\text { effectiveness and impact of the educational tools used. }\end{array}$ \\
\hline Brand $\mathrm{P}^{38}$ & Commentary & COVID-19 & $\begin{array}{l}\text { Medical students and } \\
\text { clerkship student }\end{array}$ & Well-being should be considered as well. \\
\hline Wang et $\mathrm{al}^{39}$ & Commentary & COVID-19 & $\begin{array}{l}\text { Medical students and } \\
\text { clerkship student }\end{array}$ & $\begin{array}{l}\text { Medical students and clerkship students might return in } \\
\text { advance if situations permit. }\end{array}$ \\
\hline $\begin{array}{l}\text { Hofmann et } \\
\mathrm{al}^{40}\end{array}$ & Commentary & COVID-19 & $\begin{array}{l}\text { Clerkship students } \\
\text { only }\end{array}$ & Support for conducting virtual COVID rounds. \\
\hline Shih et $\mathrm{al}^{41}$ & Commentary & COVID-19 & Medical students only & $\begin{array}{l}\text { E-learning provides feedback to clinical teachers on how } \\
\text { undergraduate medical students acquire knowledge } \\
\text { best. }\end{array}$ \\
\hline Roskvist et al ${ }^{42}$ & Commentary & COVID-19 & Medical students only & $\begin{array}{l}\text { The challenge is defining how much learning can be } \\
\text { undertaken online, and how much clinical exposure is } \\
\text { still necessary. }\end{array}$ \\
\hline Rafeh et $a^{43}$ & Editorial & COVID-19 & $\begin{array}{l}\text { Clerkship students } \\
\text { only }\end{array}$ & $\begin{array}{l}\text { Student participation is facilitated and encouraged in } \\
\text { learning virtually. }\end{array}$ \\
\hline Singal et $\mathrm{al}^{44}$ & Editorial & COVID-19 & Medical students only & $\begin{array}{l}\text { Traditional cadaveric dissection has already been } \\
\text { partially encroached by technological advances before } \\
\text { this pandemic. }\end{array}$ \\
\hline Pitt et $\mathrm{al}^{45}$ & Commentary & COVID-19 & $\begin{array}{l}\text { Medical students and } \\
\text { clerkship student }\end{array}$ & $\begin{array}{l}\text { Educational innovations are needed in unprecedented } \\
\text { times like this. }\end{array}$ \\
\hline Gill et al ${ }^{46}$ & Commentary & COVID-19 & $\begin{array}{l}\text { Medical students and } \\
\text { clerkship student }\end{array}$ & $\begin{array}{l}\text { Medical schools and postgraduate training } \\
\text { organisations will need to be flexible, responsive, and } \\
\text { creative in how they adapt to educating. }\end{array}$ \\
\hline Park et al ${ }^{47}$ & Review & MERS & Medical students only & $\begin{array}{l}\text { Medical schools should maintain constant } \\
\text { communication with teaching hospitals and consult } \\
\text { with health authorities and experts. }\end{array}$ \\
\hline $\begin{array}{l}\text { Sherbino et } \\
\mathrm{al}^{48}\end{array}$ & Perspective & SARS & $\begin{array}{l}\text { Clerkship students } \\
\text { only }\end{array}$ & $\begin{array}{l}\text { Consider the impact on future education before the } \\
\text { next storm arrives. }\end{array}$ \\
\hline
\end{tabular}


and 3,962 papers on SARS and medical education (55 from Pubmed and 3,907 from Science Direct). After duplicates were removed, 4,605 papers were then scanned according to the inclusion and exclusion criteria and about 182 papers were included for fulltext screening. In the end, 24 papers were included in this study after screening each paper's suitability according to PRISMA guidelines (Figure 1). All the studies included are shown in Table 1.

\section{Discussion}

\subsection{The impact of COVID-19 pandemic on medical education}

COVID 2019 emerged in Wuhan at the end of December 2019 and the disease spread quickly affecting other parts of the China. Wuhan authorities announced the city's lockdown on the $23^{\text {rd }}$ of January 2020 to slow down the transmission and not long after, the other cities followed suit. In the following weeks, the disease became a worldwide outbreak and the WHO announced that it is a global threat. While China with its aggressive action has succeeded in reducing the number of new cases, some countries namely Iran, Italy, and US have yet succeeded. ${ }^{32}$ To further limit the spread of COVID-19 and avoid overburdening the healthcare system, several countries have implemented various forms of lockdown. ${ }^{25,38}$ Other measures have been put into action, such as social distancing, self-quarantine or isolation, closing public facilities, including institutions, museums, places for large gatherings, which included universities and schools. ${ }^{32}$ The Centers for Disease Control and Prevention (CDC-P) recommended cancellation of large conferences and limitation of regular meeting sizes. ${ }^{29}$ Over $91 \%$ of students all around the world are affected by the closing of education institutions in their countries. ${ }^{36}$ In total, there are more than 900 million learners who have been affected. ${ }^{49}$ In response to the emerging healthcare crises, many medical faculties and hospitals changed their regulations. They prioritize healthcare services for COVID-19 cases by expanding the intensive care units (ICU) capacities and allocating healthcare professionals to handle COVID-19 cases. Most non-essential operations are postponed, routine follow-up or visits are either postponed or done through video call, and hospital stall are encouraged to work from home. ${ }^{38}$

Several countries took different measures in continuing medical education. The American Association of Medical Colleges (AAMC) released guideline recommendations to suspend any clinical activities for a minimum of two weeks, and strongly suggest that medical students should not be involved in patients' care. $^{30}$ In Italy, the total number of COVID-19 cases is increasing rapidly, passing China with the most case related deaths in March, 2020. The Italian government took specific measures by changing the rules of the Italian medical board examination, resulting in almost 10,000 medical students who were able to directly contribute in the healthcare services without taking the postgraduate examination. ${ }^{33}$

Since the institutions that provide medical education are deeply affected by the pandemic, medical educators are in need to find new ways to keep the students engaged in their education. Some universities have shifted face-to-face classes to online education to provide various courses and programs, and some have replaced the live clinical exposure to the virtual one. ${ }^{26,32}$ This adjustment might be difficult for both students and instructors, and therefore might impede the progress of medical education.

\subsection{The importance of continuing medical education}

Changes are often challenging, but the consequences of not continuing medical education will outweigh any benefit of not continuing the effort altogether. Postponing clinical rotations will later impair clinical training experience, because this will lead to an overload of clerkship students next year in order to catch up with the altered curricula. ${ }^{25}$ Delaying medical education will also postpone medical students' graduation, thereby impeding their process to pursue the next step in their education and career. For final year students, the certainty of graduation is critical because we cannot overlook the possibility of a medical workers shortage in the unforeseen future of this pandemic. While it is important to continue medical education, academic medical centers should also consider the effectivity of methods used in order to align with the adjusted medical curriculum 
timeline as well as infection control measures. ${ }^{26}$

\subsection{What we can learn from past pandemics or epidemics}

Similar to the current pandemic, past coronavirus epidemics have changed medical education. Reflecting back on the SARS epidemic in 2003, clinical clerkships and electives were halted in Chinese and Canadian medical schools after 16 medical students in Hong Kong were infected by SARS following a visit to an infected patients' room. Education was continued by means of online problem-based learning. ${ }^{36}$

From one medical school experience in Korea during the MERS epidemic in 2014, some actions were taken to ensure students' safety, minimize loss of learning, and reduce anxiety and concern of staffs and students. Because of the high risk of MERS infection among students, the clerkship rotations were discontinued. Several precautions were implemented, such as frequent handwashing and sanitizing, taking daily temperature, and using masks. Lectures and classes were held with the use of a previously installed remote lecturing system linking the hospital and the main campus. The instructors delivered the lectures in the hospital classroom while the students attended the classes at the main campus. The lectures were video-recorded so students were able to watch the lectures and at the same time this lecturing system allowed instructors and students to be as interactive as if they were in the same classroom. ${ }^{47}$

\subsection{Medical undergraduates' education}

Learning for medical undergraduates/pre-clinical students has shifted from classroom to e-learning until an undefined date and time. During this time, learning has to be remote and are in technologyenabled formats. ${ }^{45}$ Online platforms such as Zoom ${ }^{\mathrm{TM}}$ Microsoft Teams $^{\mathrm{TM}}$, Skype $^{\mathrm{TM}}$, Google Classrooms ${ }^{\mathrm{TM}}$, Google Meetings ${ }^{\mathrm{TM}}$ and Whatsapp ${ }^{\mathrm{TM}}$ have been widely used to convert classroom lectures and group discussions to online discussions. . $5,27,29,36$ Maintaining discussions are often done by encouraging students to communicate via chat-boxes and microphones..$^{27,41}$

On the other hand, the shift from laboratory practice to online learning is trickier, because this limits students' access to cadavers, models, microscopic slides, and specimens. In anatomy, human cadaver studies are deemed to be the most effective method to understand human anatomy. ${ }^{50,51}$ During the pandemic, anatomic studies have been shifted to online discussions and practical sessions (dissecting cadaver) have been substituted by 3D virtual resources and digitalized cadaveric resources (cadaveric images and videos). ${ }^{36}$ These technologies are promising but might not be adequate to replace actual specimens, which help students to appreciate spatial orientation, visualization and normal variation of the human body anatomy. ${ }^{36,44}$ Clinical skills labs which simulate clinical settings are also affected. While the traditional face-to-face discussion is not feasible, written materials, video tutorial and online discussions are still being utilized. ${ }^{41}$

Online learning also involves several setbacks. Online formats require uninterrupted Internet connection and gadget compatibility, which might be challenging for students and academic centers that are located in rural areas or have limited resources. ${ }^{36,39}$ In addition, academic centers and educators might not be ready to adapt to the new technology required and this might hinder the effort of maintaining quality education. ${ }^{25,39}$

Although challenging, certain aspects of online learning might be superior to classroom learning. During online learning, students have more freedom to study at their own pace and in a personally preferred environment. ${ }^{25}$ Many students also feel more confident to ask or discuss with their lecturers via online platforms, thus helping them to be more active in learning activities. ${ }^{28,41} \mathrm{~A}$ single-center mixed methods study by Singh et al. on medical education with a total of 208 correspondents showed that many students feel that the interaction with teachers is better $(27 \%)$ or as good as $(27.8 \%)$ the regular classroom. ${ }^{27}$ Online learning is also boundless by distance and time, and therefore more students worldwide have the opportunity to access and share different types of knowledge through online contents. ${ }^{35,37}$

\subsection{Clerkship programs for medical students}

On the other hand, clerkship programs have suffered 


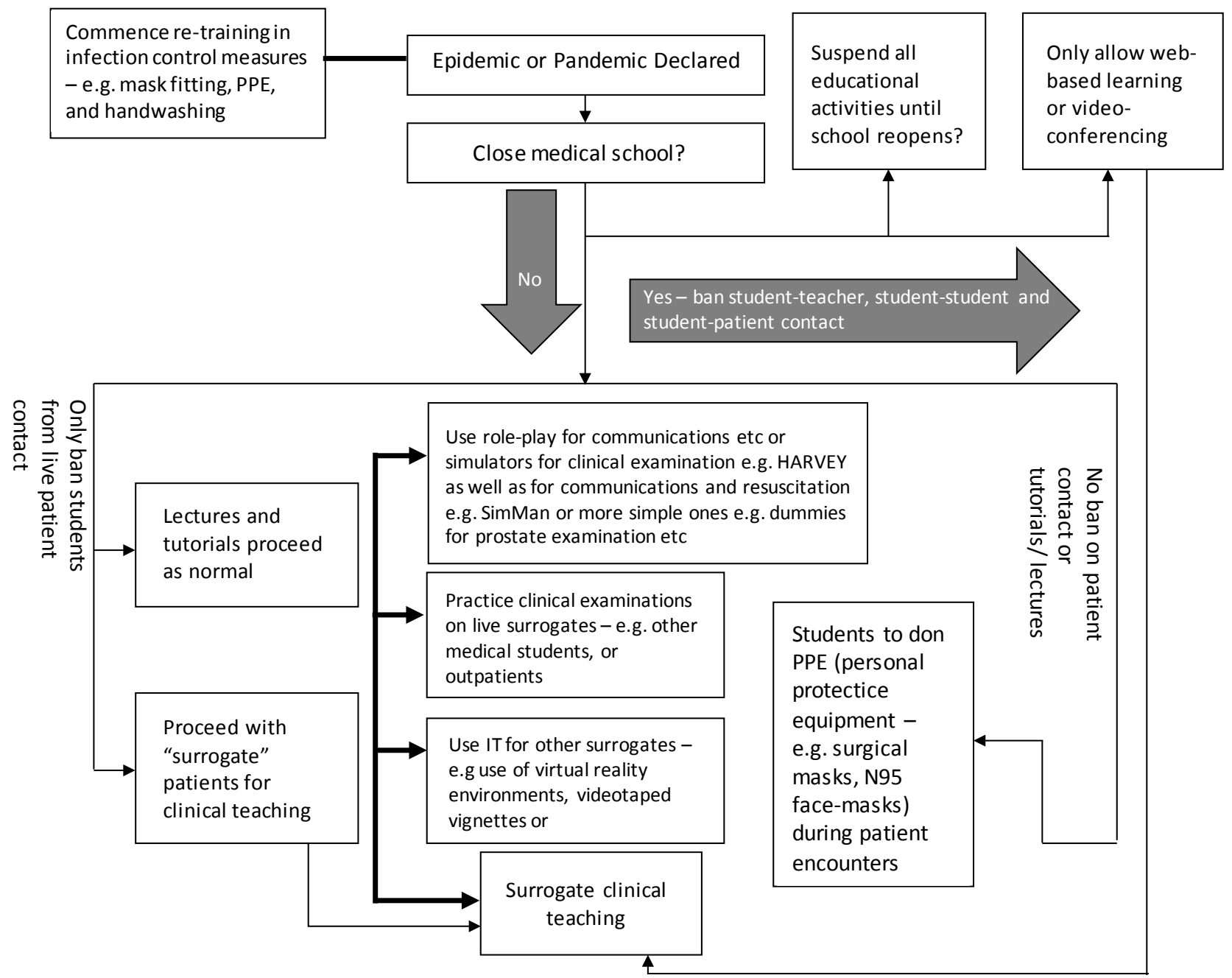

Figure 2. Decision tree for utilising different teaching methods during a pandemic or epidemic. ${ }^{53}$

greatly. Clerkship programs consist of bed-side teaching, emergency settings and surgery training that allow first-hand experience with patients. This is an integral part of medical education that cannot be easily replaced by online platforms. Similar to undergraduates, clinical learning has often reverted to online learning. ${ }^{42}$ Surgical trainings are very limited now since only essential personnel are allowed in operating rooms and the content has often been converted into video lectures, virtual grand rounds, and other online educational networks. ${ }^{43,49}$ However, an innovation in bedside teaching has been done by using Zoom ${ }^{\mathrm{TM}}$ and gadgets to live-stream bedside rounds involving patients with COVID-19 with satisfying feedback. ${ }^{40}$

Although innovative, online clerkship programs cannot replace the conventional bedside teaching because it is designed to allow students to experience real time interaction with patients and deepen their understanding. This is also valuable for their application of residency in the future. ${ }^{30}$ Future research on the most effective methods of clerkship education should be done in order to allow students to still experience these encounters with real life patients.

\subsection{Medical students' involvement in the community as part of medical learning}

There is a question whether medical students' contribution in the community will benefit all parties or do just the opposite. Undergraduate medical students can be involved by educating their family ${ }^{39}$ and community using the online platforms ${ }^{45,52}$ in order to clarify any misinformation. While this 
benefits the community, it also encourages students to apply their public health knowledge and therefore indirectly help to stop the spread of the disease..$^{52}$

Involving final year medical students in the healthcare system has also been considered. Sahi et al. and Miller et al. indicated that with adequate protective measures and possible remuneration, medical students' involvement will benefit other medical workers and patients during the pandemic. ${ }^{14,25}$ Their involvement can also be considered as a substitution credit for their studies and thus part of continuing their education. ${ }^{14}$ Some institutions, such as Aalborg University in Denmark ${ }^{[38]}$ and University of Auckland ${ }^{42}$ involved the final year medical students in the healthcare system as essential health workers. In Italy, the high demand of medical workers led the government to fast-track final year medical students' graduation by terminating board examinations and practical training. ${ }^{33}$

However, many studies suggest that medical students are not essential workers, hence should not be involved in direct patient care. Semi-structured interviews with last-year medical students who are handling infected patients by Tabari et al. show that many of them are not prepared to face the unexpected problems during their service learning. These include psychological distress, crises management, and public health education issues. ${ }^{34}$ The increasing number of patients is also parallel with the increasing demand of personal protection equipment (PPE), therefore hospitals might not have enough PPE and testing kits for their own healthcare workers, let alone medical students. ${ }^{14}$ For these reasons, the risks of poor outcomes from adding medical students to the frontline might outweigh the benefits. Ultimately, involving students in direct healthcare should not only be considered based on hospitals' needs for more healthcare forces, but also stakeholders' ability to provide adequate PPE, testing kits, ensure safety, and prioritize students' education above anything else.

\subsection{Future Considerations}

The medical field ultimately depends on the cultural view of each generation. The older belief holds that going to work even though they are sick and overworked is altruistic and compassionate. However, in this pandemic where being even asymptomatic might facilitate viral transmission to other patients forces everyone to consider the effects of these potential actions, even though it may be done with good intentions.

Other important aspects to consider are the need to develop a standardized testing and clerkship protocol as well as residency programs which ultimately will be the front-liners. Universities need to be agile and flexible in order to adjust some parts of their strategies in order to free up their final year students to help with this pandemic by allowing them to graduate earlier as stated above..$^{13}$ Figure 2 shows a decision tree that might help educators and professors on deciding the correct pathway to continuing their education programs. ${ }^{53}$

\section{Conclusion}

Change is inevitable. Institutions around the world have collaborated with students and educators on continuing medical education despite many limitations. We believe that adjustments are not impossible as e-learning has been done many times in the past and now is supported by advanced technology. This review discusses the broad spectrum of basic medical education that has been affected and presents various methods that are used around the world. Students' involvement in the community as part of medical education is also an important aspect and should be considered by weighing the benefits. While some of the medical students struggle to develop skills to help them be more competent in public health education, crisis management techniques, and mental health care, medical students can be educators in their communities by developing educational materials and videos, in which they can promote positive behaviors that can prevent the spread of the COVID-19 pandemic.

Data on students' performance and knowledge after e-learning compared to graduates with traditional learning methods are lacking; therefore, more research should be done in the future concerning these important aspects. In addition, further research on clinical students' education during this pandemic is urgently needed. With all 
of that said, academic institutions, educators and students should maximize facilities and innovate ways to maintain the quality of medical education. We encourage all parties to consistently evaluate, review, and improve the efforts of continuing medical education.

\section{Acknowledgments}

The authors received no specific grants from any funding agency in the public, commercial, or not-forprofit sectors.

\section{Conflict of interests}

None declared.

\section{References}

1. Huang C, Wang Y, Li X, Ren L, Zhao J, Hu Y, et al. Clinical features of patients infected with 2019 novel coronavirus in Wuhan, China. Lancet. 2020;395(10223):497-506.

2. Lu R, Zhao X, Li J, Niu P, Yang B, Wu H, et al. Genomic characterisation and epidemiology of 2019 novel coronavirus: implications for virus origins and receptor binding. Lancet [Internet] 2020;395(10224):565-74. Available from: http:// dx.doi.org/10.1016/S0140-6736(20)30251-8

3. Zhu N, Zhang $D$, Wang $W$, Li $X$, Yang B, Song J, et al. A novel coronavirus from patients with pneumonia in China, 2019. N Engl J Med. 2020;382(8):727-33.

4. Aji W, Dewi F, Kristen U, Wacana S. Dampak Covid-19 Terhadap Implementasi Pembelajaran Daring Di Sekolah Dasar. Edukatif J Ilmu Pendidik [Internet] 2020;2(1):55-61. Available from: https://edukatif.org/index.php/edukatif/article/ view/90

5. Purwanto A, Pramono R, Asbari M, Santoso PB, Wijayanti $\mathrm{LM}$, Choi $\mathrm{CH}$, et al. Studi eksploratif dampak pandemi COVID-19 terhadap proses pembelajaran online di Sekolah Dasar. J Educ Psychol Couns [Internet] 2020;2(1):1-12. Available from: https://ummaspul.e-journal.id/ Edupsycouns/article/view/397

6. WHO. Coronavirus disease 2019 (COVID-19) Situation Report-10 [Internet]. 2020. Available from: https://www.who.int/docs/default- source/searo/indonesia/covid19/whosituation-report-10.pdf?sfvrsn=a9ceb157_2

7. Djalante R, Lassa J, Setiamarga D, Sudjatma A, Indrawan $M$, Haryanto $B$, et al. Review and analysis of current responses to COVID-19 in Indonesia: pof January to March 2020. Prog Disaster Sci. 2020;6(April):100091.

8. Windhiyana E. Dampak COVID-19 terhadap kegiatan pembelajaran online di Perguruan Tinggi Kristen di Indonesia. Perspekt Ilmu Pendidik. 2020;34(1):1-8.

9. Kemdikbud RI. Edaran Tentang Pencegahan Wabah COVID-19 di Lingkungan Satuan Pendidikan Seluruh Indonesia. 2020;1-5.

10. Viner RM, Russell SJ, Croker H, Packer J, Ward J, Stansfield C, et al. School closure and management practices during coronavirus outbreaks including COVID-19: a rapid systematic review. Lancet Child Adolesc Heal. 2020;4(5):397-404.

11. Jackson C, Mangtani P, Vynnycky E. Impact of school closures on an influenza pandemic: scientific evidence base review. [Internet] Public Health England: 2014. United Kingdom. Available from: https://assets.publishing. service.gov.uk/government/uploads/system/ uploads/attachment data/file/316203/School Closures Evidence review.pdf

12. Maudiarti S. Penerapan e-learning di Perguruan Tinggi Santi Maudiarti Sekolah Tinggi Pariwisata Trisakti. Perspekt Ilmu Pendidik. 2018;32(1):5368.

13. Rose $S$. Medical student education in the time of COVID-19. J Am Med Assoc. 2020;323(21):21312.

14. Miller DG, Pierson L, Doernberg S. The role of medical students during the COVID-19 pandemic. Ann Intern Med. 2020;M20-1281.

15. Belingheri M, Paladino ME, Riva MA. Beyond the assistance: additional exposure situations to COVID-19 for healthcare workers. J Hosp Infect. 2020;105(2):353.

16. Whelan A, Prescott J, Young G. Interim guidance on medical students' participation in direct patient contact activities: principles and guidelines [Internet]. Assoc. Am. Med. Coll. Available from: https://lcme.org/wp-content/ 
uploads/filebase/March-30-2020-InterimGuidance-on-Medical-Students-Participationin-Direct-Patient-Contact-Activities.pdf on 31 March 2020

17. Guidance on Medical Students' Participation in Direct Patient Contact Activities [Internet]. Assoc. Am. Med. Coll.Available from: https:// www.aamc.org/system/files/2020-04/mededApril-14-Guidance-on-Medical-StudentsParticipation-in-Direct-Patient-ContactActivities.pdf

18. Academic integrity for assessments affected by COVID-19 [Internet]. Assoc. Am. Med. Coll. Available from: http://www.bris.ac.uk/medialibrary/sites/academic-quality/documents/ policy/academic-integrity-guidance-covid19.pdf

19. Emanuel EJ. The inevitable reimagining of medical education. J Am Med Assoc. 2020;323(12):1127-8.

20. Rieder MJ, Salvadori M, Bannister S, Kenyon C. Collateral damage: the effect of SARS on medical education. Clin Teach. 2004;1(2):85-9.

21. Lim E, Oh V, Koh DR, Seet R. The challenges of "continuing medical education" in a pandemic era. Ann Acad Med Singapore. 2009;38:724-6.

22. Liu M, Jiang C, Donovan C, Wen Y, Sun W. Middle east respiratory syndrome and medical students: letter from China. Int J Environ Res Public Health. 2015;12(10):13289-94.

23. Al-Rabiaah A, Temsah MH, Al-Eyadhy AA, Hasan GM, Al-Zamil F, Al-Subaie S, et al. Middle East Respiratory Syndrome-Corona Virus (MERS-CoV) associated stress among medical students at a university teaching hospital in Saudi Arabia. J Infect Public Health. 2020;13(5):687-91.

24. Moher D, Liberati A, Tetzlaff J, Altman DG. Preferred reporting items for systematic reviews and meta-analyses: The PRISMA Statement. PLoS Med. 2009;6(7):e1000097.

25. Sahi PK, Mishra D, Singh T. Medical education amid the COVID-19 Pandemic. Indian Pediatr 2020;57:652-7.

26. Ashokka B, Ong SY, Tay KH, Loh NHW, Gee CF, Samarasekera DD. Coordinated responses of academic medical centres to pandemics: sustaining medical education during COVID-19. Med Teach. 2020;42(7):762-771.
27. Singh K, Srivastav S, Bhardwaj A, Dixit A, Misra S. Medical education during the COVID-19 pandemic: a single institution experience. Indian Pediatr. 2020;57(7):678-679.

28. Kanneganti A, Lim KMX, Chan GMF, Choo S, Choolani $M$, Ismail-Pratt I, et al. Pedagogy in a pandemic - COVID-19 and virtual continuing medical education ( $\mathrm{VCME}$ ) in obstetrics and gynecology. Acta Obstet Gynecol Scand. 2020;99(6):692-5.

29. Almarzooq ZI, Lopes M, Kochar A. Virtual learning during the COVID-19 pandemic: A disruptive technology in graduate medical education. $J$. Am. Coll. Cardiol. 2020;75(20):2635-8.

30. Akers A, Blough C, lyer MS. COVID-19 implications on clinical clerkships and the residency application process for medical students. Cureus 2020;12(4):e7800.

31. Calhoun KE, Yale LA, Whipple ME, Allen SM, Wood DE, Tatum RP. The impact of COVID-19 on medical student surgical education: implementing extreme pandemic response measures in a widely distributed surgical clerkship experience. Am J Surg. 2020;220(1):4447.

32. Sahu P. Closure of universities due to coronavirus disease 2019 (COVID-19): impact on education and mental health of students and academic staff. Cureus. 2020;12(4):e7541.

33. Lapolla P, Mingoli A. COVID-19 changes medical education in Italy: will other countries follow? Postgrad. Med. J.2020; 96(1137):375-376.

34. Tabari P, Amini M, Moosavi M. Lessons learned from COVID-19 epidemic in Iran: the role of medical education. Med Teach. 2020;1-1.

35. Franchi T. The impact of the COVID-19 pandemic on current anatomy education and future careers: a student's perspective. Anat Sci Educ. 2020;13(3):312-5.

36. Longhurst GJ, Stone DM, Dulohery K, Scully D, Campbell T, Smith CF. Strength, Weakness, Opportunity, Threat (SWOT) analysis of the adaptations to anatomical education in the United Kingdom and Republic of Ireland in response to the COVID-19 pandemic. Anat Sci Educ. 2020;13(3):301-11.

37. Gonzales-Zamora JA, Alave J, De Lima- 
Corvino DF, Fernandez A. Videoconferences of infectious diseases: an educational tool that transcends borders. A useful tool also for the current COVID-19 pandemic. Le Infez Med. 2020;28(2):135-8.

38. Brand PLP. COVID-19: a unique learning opportunity if the well-being of learners and frontline workers is adequately supported. Perspect. Med. Educ.2020; 9: 129-131.

39. Wang S, Dai M. Status and situation of postgraduate medical students in China under the influence of COVID-19. Postgrad Med J. 2020;1-3.

40. Hofmann H, Harding C, Youm J, Wiechmann W. Virtual bedside teaching rounds with patients with COVID-19. Med Educ. 2020;14223.

41. Shih KC, Chan JCH, Chen JY, Lai JSM. Ophthalmic clinical skills teaching in the time of COVID-19: A crisis and opportunity. Med Educ. 2020; 54(7).

42. Roskvist R, Eggleton K, Goodyear-Smith F. Provision of e-learning programmes to replace undergraduate medical students' clinical general practice attachments during COVID-19 standdown. Educ Prim Care. 2020;1-8.

43. Abi-Rafeh J, Azzi AJ. Emerging role of online virtual teaching resources for medical student education in plastic surgery: COVID-19 pandemic and beyond. I Plast Reconstr Aesthetic Surg. 2020; 73(8): 1575-1592.

44. Singal A, Bansal A, Chaudhary P. Cadaverless anatomy: darkness in the times of pandemic COVID-19. Morphologie. 2020;3-6.

45. Pitt MB, Li S-TT, Klein M. Novel Educational responses to COVID-19: what is here to stay? Acad Pediatr. 2020;120.

46. Gill D, Whitehead C, Wondimagegn D. Challenges to medical education at a time of physical distancing. Lancet. 2020;396(10244):77-9.

47. Park SW, Jang HW, Choe YH, Lee KS, Ahn YC, Chung MJ, et al. Avoiding student infection during a Middle East respiratory syndrome (MERS) outbreak: a single medical school experience. Korean J Med Educ. 2016;28(2):209-17.

48. Sherbino J, Atzema C. "SARS-Ed": severe acute respiratory syndrome and the impact on medical education. Ann Emerg Med. 2004;44(3):229-31.
49. Dedeilia A, Sotiropoulos MG, Hanrahan JG, Janga D, Dedeilias P, Sideris M. Medical and surgical education challenges and innovations in the COVID-19 Era: A Systematic review. 2020;34(3):1603-11.

50. Darras KE, de Bruin ABH, Nicolaou S, Dahlström $\mathrm{N}$, Persson A, van Merriënboer J, et al. Is there a superior simulator for human anatomy education? How virtual dissection can overcome the anatomic and pedagogic limitations of cadaveric dissection. Med Teach. 2018; 40(7): 752-3.

51. Ghosh SK. Cadaveric dissection as an educational tool for anatomical sciences in the 21st century. [Anat Sci Educ. 2017;10(3):286-99.

52. Villela EF de M, Oliveira FM, Leite ST, Bollela VR. Student engagement in a public health initiative in response to COVID-19. Med Educ. 2020;medu.14199. A

53. Lim ECH, Oh VMS, Koh DR, Seet RCS. The challenges of "continuing medical education" in a pandemic era. Ann Acad Med Singapore. 2009;38(8):724-6. 